\title{
Italo Calvino and What's Next: The Literature of Monstrous Possibility · Curtis White
}

I 'D LIKE TO TALK about Italo Calvino (particularly his two science-fictive books of stories, Cosmicomics and $t$ zero) within the context of a more general discussion of "postmodernism" and John Barth's idea of "the literature of exhaustion." I would begin by rectifying the almost universal misunderstanding of "the literature of exhaustion" (as another sign of the death of the novel), but, fortunately, Barth's own later essay, "The Literature of Replenishment," things straight. It is enough to say that Barth's first essay, "The Literature of Exhaustion," 2 was not a gloomy prophesy of the end of the novel, or fiction, or print. Rather, both it and "The Literature of Replenishment" are about a single, happier question: What is "postmodernism" (the "what's next" of American fiction for the last fifteen to twenty years)?

As a contribution to Barth's discussion of "postmodernism," I would like to develop two metaphors, one recent bit of literary theory, and one more or less rhapsodic allusion to an "eternal verity," the human heart, love. My purpose for these fragments will not be to tell the Truth about postmodernism (no doubt an impossible, in any case an undesirable task), but, more modestly, to provide new ways of talking about and looking at it, which-when added to what has already been said about postmodernism, and what remains to be said in the next few decades-will eventually constitute postmodernism's saturation, used-upness, and exhaustion. In short, this is to be a contribution to the death of what's next.

Before setting out, I want to emphasize that I have, as Chuck Berry sang, "No particular place to go." I have no particular understanding or definition to claim privilege for. Postmodernism is usually defined through a series of literary historical "sightings." Barth catches a glimpse of it in Borges, Nabokov, and Beckett. Alan Wilde sees it in Robert Coover, Ronald Suckenick, and Raymond Federman. Federman, with greater depth of perception, sees it as far back as Rabelais, and then in Celine and Beckett. The perhaps myopic Jerome Klinkowitz can make it out best in the procreative vortex of 1967 in which 
Barthelme, Vonnegut, and Kosinski came on the scene. Or postmodernism is defined as a trans-traditional itinerary; one gets to it, through Rabelais, Sterne, Joyce, and Gilbert Sorrentino, in the same way that one gets to San Jose through San Mateo and Palo Alto. This is a way of saying what Nietzsche says in The Genealogy of Morals: "that which has a history eludes definition." Postmodernism has no definition as such, and like all other literary classifications, it has no pure examples. Its only reality is in a system of equivalences and differences. It is like Joyce and unlike James. Like Sorrentino and unlike Saul Bellow. This ought to mean that postmodernism is nothing in itself, but only whatever we say it is. That is, in fact, what I mean. For, as the aesthetician Morris Weitz has argued, art is what we as a culture decide it is. ${ }^{3}$ And surely what goes for art in general goes for art's sub-species as well.

The most I intend to do is to hold a certain kind of mirror (that we are used to calling literary commentary) up to the texts that we are used to calling postmodern and hope that there is recognition. Although we may not be able to claim that this recognition is what we used to refer to fondly as knowledge, it is much more than nothing. It is a lively, a bracing, and-above all else-a practical tautology. As the later Wittgenstein of the Philosophical Investigations would have argued here, the idea of postmodernism may not constitute a truth, but that doesn't make it any less useful. We can still use it even if we do not claim for it any truth. It can still be a tool. This is to say nothing more than what Barth says in "The Literature of Replenishment," that "critical categories are as more or less fishy as they are less or more useful."

As I have already suggested, the writers of the fiction of postmodernism are not so much interested in, or overwhelmed by the idea of exhaustion, as they are excited by other possiblities, by what is not yet tedious. In fact, contemporary fiction is a literature of great promise, productivity, and possibility. It is a literature of monstrous possibility. In Italo Calvino one may find an indication of as well as a metaphor for this largeness of possibility in two key related tropes: the regressus in infinitum, and the figure of the "monster."

The wobbly history of the notion of the regressus in infinitum is a crucial and indicative one for western culture. ${ }^{4}$ We may trace it as far

\footnotetext{
3"The Role of Theory in Aesthetics," The Journal of Aesthetics and Art Criticism, XV, No. 1, (1956). 'For a brief history of this eventful metaphor (through Zeno's paradoxes, Aristotle's "third man," Aquinas' "unmoved mover," and Kafka's “imperial messenger"), see Jorge Luis Borges' essay "Avatars of the Tortoise."
} 
back as Zeno, where it is the paradox of Achilles and the tortoise in which movement is proven impossible. For the moving object (Achilles) must run half of the distance before reaching its destination, and before reaching the half, half of the half, and before half of the half, half of the half of the half, and so on. Zeno sought through his paradox to discover the contradiction which inheres in the ordinary idea of motion.

Recently, the significance of the regressus (as paradox and critique of the conventional) has again asserted itself, this time, most notably, in the thinking of Jacques Derrida. It is the regressus in infinitum, the hopelessness of arriving at an ultimate term, that Derrida applies "deconstructively" to the desire of phenomenology to determine a "transcendental subject." ${ }^{5}$ As Husserl (whom Derrida critiques at great length in Speech and Phenomena) peels back the layers of consciousness which wrap themselves tightly about the Cartesian cogito, the causal structure of the regressus in infinitum is-at a crucial point-broken, ruptured by metaphysics, theology, and desire. Husserl was determined to find a privileged, originary break in the chain of causality which he called the "I," the cogito, His Majesty the Sovereign Self. Derrida's modest but deconstructing reminder to all of metaphysics is that, after all, the regressus is the name of a paradox (of an "undecidability"), and not, as St. Thomas Aquinas, Descartes, or Husserl would have it, of a theological, metaphysical, or phenomenological proof.

Italo Calvino uses the metaphor of the regressus in infinitum in his Cosmicomic-al story, "A Sign in Space." In it he finds the idea of the origin of language caught within the dialectical structure of the regressus. The results for his narrator, Qfwfq, and language itself are both bizarre and comic.

I conceived the idea of making a sign, that's true enough, or rather, I conceived the idea of considering a sign a something that I felt like making, so when, at that point in space and not in another, I made something, meaning to make a sign, it turned out that I really had made a sign, after all.

Here Calvino wraps himself in the contradictoriness of language trying to deliver the facts about its own origin. How conceive, how 1973). 
make, how feel? What something, what point, what meaning could there be before the first sign? Calvino asserts, comically, the undecidability, the utter perplexity of the question of the origin of signs. For the existence of a sign is dependent upon the assumption of the existence of other signs before it. There is always already an earlier sign.

I thought about it day and night; in fact, I couldn't think about anything else; actually, this was the first opportunity I had had to think something; or I should say: to think something had never been possible, first because there were no things to think about, and second because signs to think of them by were lacking, but from the moment there was that sign, it was possible for someone thinking to think of a sign, and therefore that one, in the sense that the sign was the thing you could think about and also the sign of the thing thought, namely, itself.

If it is true that the history of all western thought is the history of the fate of a handful of metaphors, the present stature of the regressus in infinitum, once again-as in Zeno-a deconstructing paradox, is instructive. Through the regressus, an important part of literary postmodernism (certainly Borges, Calvino, and Barth, ${ }^{6}$ all rooted in Nietzsche and Kafka) seems to be saying, in Borges' words, "We ... have dreamt the world. We have dreamt it as firm, mysterious, visible, ubiquitous in space and durable in time; but in its architecture we have allowed tenuous and eternal crevices of unreason which tell us it is false."

If, couched in our postmodern period, we may not speak of origins, or dream the world as "ubiquitous in space and durable in time" without tainting ourselves with theology and metaphysics, how shall we explain the "presence" of things (you know: chairs, streets, people, bad manners) in our stories? What shall we say about them? The ultimate thrust of the deconstructions of Zeno, Derrida, Borges, and Calvino is to cut us off from time, space and matter, that is to say, from the mimetic impulse. But what sort of "reality"can fiction have deprived of all claim to referentiality?

One may discern in Calvino two related responses to this question.

'Note Barth's use of the regressus in Lost in the Funhouse-moebus strips, mise en abime mirror structures-and in Chimera-infinite declensions of tellers and tales.

'Borges, Labyrinths (New York: New Directions, 1964), p. 208. 
The first, arrived at, again, in the story "A Sign in Space," is that the only reality the cosmos has is the reality of signs. The sign which Calvino's Qfwfq created, “inhabited me, possessed me entirely, came between me and everything with which I might have attempted to establish a relationship." As the story concludes even more forcefully, "independent of signs, space didn't exist and perhaps had never existed."

Although this is a lot, this isn't all Calvino has to say on the question of presence. What about, for example, the presence of birds? Calvino begins his short story "The Origin of the Birds" ( $t$ zero) with Qfwfq saying that in order to tell the story of the origin of birds he would have to "remember better how a number of things were made, things I've long since forgotten; first the thing I now call bird, second what I now call I, third the branch, fourth the place where I was looking out, fifth all the others." In the place of what Qfwfq had "long since forgotten" (origins: how things were made), Calvino supplies the figure of the monster, "all those who could exist and didn't." Qfwfq tells the story this way:

One morning I hear some singing, outside, that I have never heard before. Or rather (since we didn't yet know what singing was), I hear something making a sound that nobody has ever made before. I look out. I see an unknown animal singing on a branch. He had wings feet tail claws spurs feathers plumes fins quills beak teeth crop horns crest wattles and a star on his forehead. It was a bird; you've realized that already, but I didn't; they had never been seen before.

The appearance of the bird is profoundly unsettling for Qfwfq and his community. The wisest among them, old $\mathrm{U}(\mathrm{h})$, speaks to his neighbors in the name of tradition. "Don't look at him!" he says. "He's a mistake!" But Qfwfq takes a more difficult and risky line.

Hadn't we been told over and over that everything capable of being born from the Reptiles had been born? ... For many years we had been tormented by doubts as to who was a monster and who wasn't, but that too could be considered long settled: all of us who existed were nonmonsters, while the monsters were all those who could exist and didn't.... But if we were going to begin again with strange animals, ... 
if a creature impossible by definition such a bird was instead possible. ... then the barrier between monsters and nonmonsters was exploded and everything was possible again.

What I would like to suggest is that this idea of a presence grounded not in original birdiness, but rather in a monstrous and disruptive paste-up of mutative reptile and fish is not only an important philosophical idea (because it implicitly denies a metaphysical/theological origin), but a crucial literary distinction as well. For there is a monstrous figure in the carpet here: the story is told through descriptions of comic strip frames. Calvino as author, as much as Qfwfq as character, is "the promotor of a process of refusal to see and say things the way they had been seen and said up to that very moment."

The literature of postmodernism generally aspires to origin as rupture, break, mutation, transformation. It prefers the discontinuous and the monstrous to the linear and archetypal. Consider, for example, that there is no possibility for the monstrous in Northrop Frye's mythopoeic literary universe. In that cosmos literature's lineage is proper-Hamlet rooted in ur-Hamlets rooted in universal myth-and its papers and credentials are in order. But from Rabelais' gargantuan, encyclopaedic farce, through Fielding's comic epic-poem in prose, Sterne's autobiography in utero, Joyce's comic catalogues, Federman's exaggerated secondhand tale to be read aloud either standing or sitting, Barth's Fiction for Print, Tape and Live Voice, and, surely the most appropriate example of all, Barth's triptych, Chimera, the inclination of the postmodern, which is to say of the anti-mimetic, has been for the hybrid, for the a-generic. Of course, these monstrous genres are meant to show that the norms defining monstrosity are themselves "originally" monstrous. This is precisely the shock of Qfwfq's insight: the line has been crossed; we are all monsters.

However, aside from the undecidable question of the original constitution of parts, Calvino's monsters (whether biological or literary) are always recognizable in their parts. It is never a question of creation from nothing, but only of newness as a recombination of previously existing parts. Calvino sees the creation of narrative as "a combinatorial game which plays on the possibilities intrinsic to its own material."

This seems to me to be an important theoretical assertion. It is to say

${ }^{8}$ Calvino, "Myth in the Narrative," in Surfiction, ed. Raymond Federman (Chicago: The Swallow Press), p. 80 . 
that the storyteller is not Shakespeare's old mimeser (with his mirror held to nature), nor even, in any simple sense, Joyce's old artificer (that high priest to the Imagination), but rather something much more like Claude Levi-Strauss' bricoleur. In the chapter "The Science of the Concrete" in The Savage Mind, Levi-Strauss defines the bricoleur as one whose "universe of instruments is closed" and who must "make do with whatever is at hand." The bricoleur is "imprisoned in the events and experiences which [he] never tires of ordering and re-ordering in [his] search to find them a meaning."

So, the monstrousness of postmodernism's literary possibilities is the result, on the one hand, of the debunking or deconstructing of certain central conventions of 19th century literary realism (especially of the notions of mimesis and genre); and, on the other hand, of the willingness to allow narrative's newly released parts to float, mingle and re-cohere. The realist values the reassurance of the familiar; the excitable postmodernist-a curious bricoleur-values the beauty of the new and "monstrous." As Qfwfq would say, "the barrier between monsters and nonmonsters [is] exploded and everything is possible again" [my italics].

As relevant as the regressus in infinitum and the figures of the monster and the bricoleur seem to what is central in Calvino's fiction and in postmodernism in general, one is forced to admit that most of Calvino's tales of Qfwfq in Cosmicomics and $t$ zero are, from a certain perspective, pre-eminently recognizable, hardly monstrous, tales of love, loneliness and philosophical gloom and glee. Calvino is clearly one who manages, as John Barth writes, "to speak eloquently and memorably to our still-human hearts and conditions, as the great artists have always done." But what does Barth mean by our "still-human hearts and conditions"? Is it true of Calvino? And if it is, how does it work with what we have to this point characterized as postmodern?

It seems to me that just beneath the surface of the modernistpostmodernist tradition, just under its icy theoretical and structural speculations, just beyond its often acid criticism of the bourgeois, is a stratum of a certain kind of sentimentality. Consider, briefly, Proust's Swann's Way.

Proust's official attitude towards "representation" is something like 
"one never gets to put down the book." In the opening passage of Swann's Way, the narrator has been reading, has put down his book, has slept, dreamt and become the subject of his book, and then awoken to try to put down the book once more. Consciousness is textual, for Proust, and reality is the supplementary "structure of recollection." A place is real for the narrating Marcel only if one has heard, or read about it beforehand and had time to imagine, and dream about its particular character.

In the same way, Swann's love was nothing in itself, but existed only to the extent that he could base it upon his own "sound, aesthetic foundation." The truth of his love is, as the narrator points out repeatedly, composed not so much by a person, Swann's lover, Odette, as by "a face deserving to be found in Botticelli" and a phrase of music.

Even one's experiences and emotions (that is, one's subjectivity) are authored by outside others. For even though the narrator authors Swann's story, Swann's experiences are more importantly the author of the narrator's own experiences in love. For the narrator would never have had his feelings for Gilberte (who was also "authored" by Swann) if he hadn't known of Swann's feelings for and experiences with Odette. $\mathrm{He}$ is that distinguished Frenchperson, descendant of Stendahl's Julian Sorel and Flaubert's Emma Bovary, who never would have fallen in love if he hadn't read about it first.

And yet in spite of Marcel's lucid speculations on the supplemental and textual nature of all experience-especially the romantic-love and beauty, as they take their places in his life, are overwhelming. In short, the presence of romantic love in Proust's fiction is so central and powerful that theory seems ultimately inconsequent: all that we know not to be-is utterly real.

Much the same sort of contradictory impulse exists in Calvino. Alongside his rigorous passages on the nature of the cosmos as the realm of signs, there is an attitude towards love/sex as a chemical/organic foundation, as an originary disposition of living matter or cells (much like, perhaps, John Barth's sperm cells in "Night-Sea Journey" which launch themselves into the unknown with the cry of "Love! Love! Love!"). Take, for example, this passage from the story "The Distance of the Moon" in Cosmicomics. Qfwfq is trying to overcome the attraction of the moon-which, in this story, hangs at only a distance of yards from the earth. 
'Hold on! Hold on to us!' they shouted at me, and in all that groping, sometimes I ended up by seizing one of Mrs. Vhd Vhd's breasts, which were round and firm, and the contact was good and secure and had an attraction as strong as the Moon's or even stronger, especially if I managed, as I plunged down, to put my other arm around her hips, and with this I passed back into our world.

Thus, Calvino's cosmic character settles on the breast of the lover, in the breast of the mother, in the breast of nature, in the breast of the cosmos.

Most of Calvino's stories are about either the change caused by biological evolution or the change caused by distancing (the gradual, or exploding expansion of the universe). Evolution from a happy original state when, as in the story "Blood, Sea" ( $t$ zero), we were present in the sea and the sea was present in us; and expansion in the cosmos to the point were the galaxies are "gradually reduced to the last tail of the last luminous ray," become metaphors for loneliness which create, in turn, a powerful nostalgia for lost origins.

In "The Spiral," a story about the social life of a molusc, we glimpse this radiant origin:

I knew that some of the others were female. The water transmitted a special vibration, a kind of brrrum brrrum brrrum, I remember when I became aware of it the first time, or rather, not the first, I remember when I became aware of it as a thing I had always known. At the discovery of these vibrations' existence, I was seized with a great curiosity, not so much to see them, or to be seen by them either ... but a curiosity to know whether something would happen between me and them. A desperation filled me, a desire not to do anything special, which would have been out of place, knowing that there was nothing special to do, or nonspecial either, but to respond in some way to that vibration with a corresponding vibration, or rather, with a personal vibration of my own, because, sure enough, there was something there that wasn't exactly the same as the other, I mean now you might say it came from hormones, but for me it was very beautiful.... In other words, I had fallen in love. 
This caring or this nostalgia, this sentiment or this generosity, this desire to spare love from what is otherwise a thorough and materialist critique of certain philosophies, myths and romances which have dominated our literature and culture since the 19th century and before, this, too, is a prominent part of both modernism and postmodernism. It can be found in Molly Bloom's universal "yes," in the helping touch of the hands of "the ladies" in Kafka's "The Hunger Artist," in Humbert Humbert's rhapsodic, albeit glandular, desires, negatively in any number of Donald Barthelme's "sad" stories (like"Critique de la Vie Quotidienne"), and in the tireless love of Lady Amherst and Ambrose Mensch in John Barth's Letters. "Love" is, perhaps, that baby in the bathwater of realism that much postmodernism does not for the moment care, or dare, to throw out. Without it there is, perhaps, only that terrifying loneliness which, as Wallace Stevens put it, is "nothing to have at heart."

I would like finally to retreat a step in my argument in order to say that postmodernism, even though it values and uses the figure of the monster, is no recent disruption or monster itself (except perhaps as an eternally recurring monster). Postmodernism is the locus of a "crisis of language" (Roland Barthes) which is at least as old as Rabelais and, if we knew where to look for it, certainly older. It is, simply, a part of the Other Tradition of anti-mimesis, that much vilified and unholy mirror reflection of F.R. Leavis' Great Tradition. Now, this would be no great thing, and postmodernism could make for itself no claim for great or surprising profundity, except for the fact that the relationship between the two has been highly charged with cultural, ideological, and political values. The need to react against the orthodoxy of realism is more than what John Barth contends, that is, it is more than a simple matter of the exhaustion of 19 th century and modernist modes. For the confrontation between realism and "experimentalism" is not only a narrow, provincial, literary dispute, it is also part of a broader ideological battle between not necessarily but factually combative epistemologies. Realism has become a State Fiction, a part of the machinery of the political state. It is through the conventions of Realism that the State explains to its citizens the relationship between themselves and Nature, economics, politics, and their own sexuality. This massive epistemological exercise takes place every day, right before our eyes on television, 
in the movies, in Time magazine, in the simple-minded, relational rhetoric of politicians, and so on. What postmodernism has done and continues to do is oppose any totalizing fiction of life, that which, in Calvino's words, seeks "to confirm and consecrate the established order of things."

Of course, ideally, the two sides could live peacefully. The fact of the matter is that they cannot live separately (although that fact can be occluded or denied for political reasons). The mimetic needs the antimimetic if it is not to become redundant and authoritarian; it needs the consciousness and the good conscience of its own ultimately fictive base (which the anti-mimetic provides). Likewise, the anti-mimetic needs to be aware that it is always at some level part of what it critiques. It needs the as-if of referentiality unless it desires to break down into "writing at the zero degree," or "white writing," or the Writerly, or any other dream text of the avant-garde, the only knowledge of which we have is that there are no examples of it. ${ }^{10}$ This is to say that no texts are mimetic and that, nevertheless, all texts must behave, at some level, as if they were. In short, mimesis and anti-mimesis, realism and experimentalism are oppositions which exist only through an exercise of force, and which, therefore, tell us as much about the politics of our own time as they do about language or literature.

And so, finally, Calvino is an exemplary postmodernist not only because he is one of those few people "whose artistic thinking is as hip as any French novelist's, but who manages nonetheless to speak to our still-human hearts and conditions," but also because, as Barth does not seem to consider, Calvino sees the confrontation between modernismpostmodernism and realism not as a narrowly literary dispute, but rather as an important part of a much larger cultural confrontation over the frontiers of knowledge and power. This overtly political aim is implicit in his fiction, implicit particularly in the way his play with science fact disrupts our conventional understanding of the world. But Calvino is explicit in his essay, "Myth in the Narrative":

When written literature comes into being, it already bears the burden of the duty to confirm and consecrate the established order of things, a burden from which it slowly frees itself ... [in order to] express the very oppressions [it] labors beneath, 
to bring them to full consciousness and to transmit this consciousness to the culture and thought of a whole society. ${ }^{11}$

${ }^{11}$ Calvino, p. 80-81. 